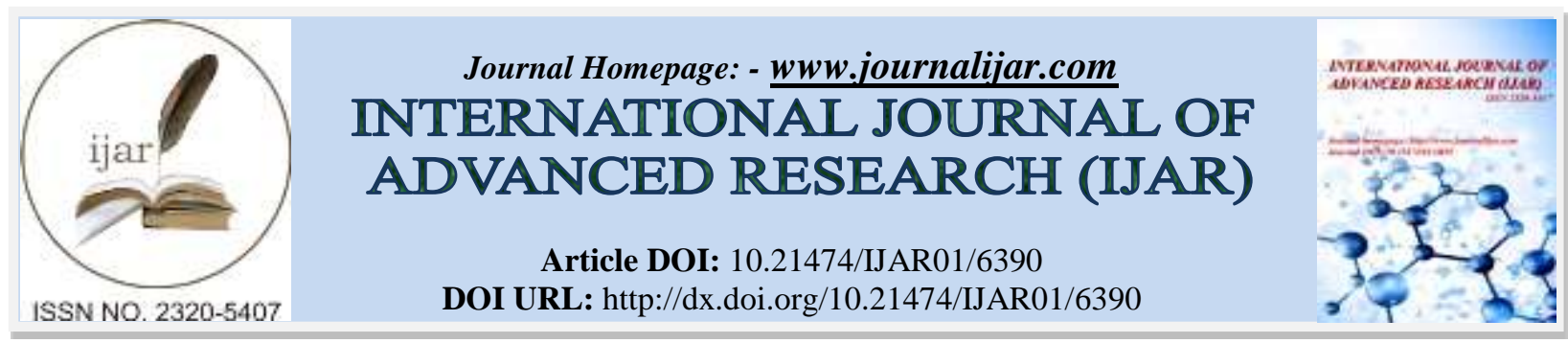

RESEARCH ARTICLE

\title{
THE EFFECT OF MANAGERIAL SKILLS AND COMMITMENT TOWARD HEAD MASTER'S JOB SATISFACTION OF MTS PRIVATE SCHOOLS IN SOUTH TANGERANG AND TANGERANG REGENCY (2018).
}

\begin{abstract}
Abdul Aziz.
Manuscript Info

Manuscript History

Received: 23 November 2017

Final Accepted: 25 December 2017

Published: January 2018

Key words:-

Job Satisfaction, Managerial Skills, And Commitment.

Abstract

The purpose of this research is to know the effect of managerial skills and commitment toward head master's job satisfaction of MTs private schools in South Tangerang and Tangerang regency.The research was conducted using survey method with quantitative approach and path analysis technique. The population of this research is 74 headmasters. Research samples selected as much as 62 headmasters using proportional random sampling technique. The data obtained through questionnaires and analyzed using path analysis techniques. Based on the results of data analysis in this research it is concluded: (1) the managerial skills have positive direct effect to job satisfaction; (2) the commitment have positive direct effect to job satisfaction; (3) the managerial skills have positive direct effect to commitment. The job satisfaction can be improved through improvement of managerial skills and commitment.
\end{abstract}

Copy Right, IJAR, 2018,. All rights reserved.

\section{Introduction:-}

The national education system is a government effort in building Indonesian people who have the behavior and personality, knowledge management and have a good achievement motivation for the goals and objectives of education that aspire it can be achieved. The position of the principal is a strategic position and is envisioned by all teachers in addition to the existence of allowances and facilities provided by the school and other things that make a principal have a powerful position. The position of the principal is quite difficult to penetrate by teachers who rely solely on the skills and knowledge of management, it takes some political effort in lobbying to get that position. In line with it, there are consequences that must be met by a principal. The principal is required to have the characteristics and competencies that support his duties and functions in running the school. The success of the principal in determining the policy, to face changes in the field of education is largely determined by his ability to lead the school. Competent in conducting monitoring and evaluation is essential in order to ensure that all components of school system functioned optimally, because when there is one component of school system that cannot function optimally, it will disrupt other components function.

A deep knowledge of education management is important to a principal. The management includes inputs, processes, and outputs. Input consists of planning and evaluation, curriculum, learners, school relationships with the community, and school climate. The process of education is focused on teaching and learning activities. The output is the acquisition achieved by learners. Therefore, principals who know about systems, processes, procedures that are systematic in formulating, implementing and evaluating educational policies will be gripped. The results of managerial knowledge and organizational structure will have an impact on job satisfaction. This is because the 
satisfaction of the principal's work will appear when someone likes his job. Job satisfaction will be gained if there is a match between expectations and reality gained from school workplace. Principal work satisfaction will be obtained when he / she succeeds in applying his managerial knowledge supported by commitment. This is interesting to be studied further.

\section{Job Satisfaction:-}

Jason Colquitt Jeffery A. Lepine and Michel J.Wsson (2015:98) stated that job satisfaction is defined as a pleasurable emotional state resulting from the appraisal of one's job or job experiences.

Then James L. Gibson, James H. Donnely, Jr Jhon M. Ivancevich, Robert Konopaske (2012:102) said that Job satisfaction is an attitude that individuals have about their jobs. It results from their perceptions of their Jobs, based on factor of the work environment, such as the supervisor style, condition, and fringe benefit.

According to John R. Schermerhorn (2011:388) job statisfaction is the degree to which an individual feels postive or negative about various aspects of work.

A similar opinion is raised by Stephen P. Robbins, Timothy A. Judge (2003:108), they stated that job statisfaction is positive feeling about a job resulting from an evaluation of its characteristics is clearly broad.

Then Lussier (2013:164) proposed job statisfaction as a set of atitudes toward work, what most employes want from their jobs, even more than they want job security or higer pay.

Based on the description of the concept of job satisfaction above, it can be synthesized that job satisfaction is the emotional response, to his work and work experience in an organization with indicators 1) Feelings of work, 2) Feelings towards colleagues, 3) Feelings of appreciation, 4) Feelings of responsibility, and 5) Feelings of selfdevelopment.

\section{Managerial Skills:-}

John R. Schermerhorn, Jr (2011:43) said that knowledge management is the process of using intelectual capital for competitive advantage.

Thomas S Bateman, Scott A. Snell (2015:6) defined knowledge management as the set of practice aimed at discovering and harnessing an organizations intelectual resources fully utilizing the intelects of the organization people.

Richard L. Daft (2008:686) stated that knowledge management is the proses of sistematically gathering knowledge, making it widely available through the organization and fostering a culture of learning.

Laurie J. Mullins (2010:187) explained that knowledge management is usually defined in terms of a range of practices or processes to identify, creates, distribute and share knowledge thought the organization.

Robert Kreitner, Angelo Kinicki (2010:345) said knowledge management as the development of tools, process, system, structure and cultures explicity to improve the creation, sharing and use of knowledge critical for decision making.

Based on the description of the concept of managerial skills above, it can be synthesized that managerial skills is everything that is known, understood, and applied someone in managing resources to achieve organizational goals effectively and efficiently with indicators; 1) Planning Ability, 2) Organizing Ability, 3) Ability to Evaluate Teacher Performance, 4) Principal Leadership.

\section{Commitment:-}

Wagner and Holenberg (2010:111) defined commitment as the degree to wich people identify withthe organizaton that employes them.

Aaron Cohen (2003:xi) said commitment is a force that binds an individual to a course of action of relevance to one or more targets. 
Robbins and Coulter (2012:260) suggested that unifed commitment is caracterized by dedication to the team's goals and willingness to expend extraordinary amounts of energy to achieve them.

According to Priyadarma in Balian (2013:18), commitment is a strong intention or full of seriousness to carry out the duties and obligations it carries or entrusted to it, or a promise or utterance (uttered) by or someone.

Mulyasa (2007: 51) also explained that self-commitment needs to be built on every individual of the school community including teachers, especially to eliminate the set of thought and culture of bureaucratic rigidity, such as having to wait for clues by turning it into creative and innovative thinking. The commitment can be achieved through several activities, such as; Building on the importance of tasks that responsible in, simplifying the complex tasks, and tasks completion oriented.

Based on the definition of the concept that has been described, it can be synthesized that commitment is a strong intention with full seriousness to carry out the duties and obligations that it bears with indicators: 1) Serenity to perform tasks, 2) Dedication that can be accountable, 3) The seriousness to achieve what they will achieve.

\section{Research Methodology:-}

This research was conducted to principals of MTs private school in South Tangerang City and Tangerang Regency for 3 (three) months. The method used in this research is survey with quantitative approach. The population is principals of MTs private school in South Tangerang City and Tangerang Regency with 74 principals with a total sample of 62 principals. The data collected in the study were collected through questionnaires in the form of rating scale with a score range of 1 to 5 .

After conducted descriptive analysis, it is continued with test requirement analysis in the form of normality test, data linearity test and regression significance, hypothesis test by using path analysis technique.

\section{Result and Discussion:-}

The Influence of Managerial Ability to Job Satisfaction:-

The results of this research indicate that managerial skills gives direct positive influence to job satisfaction. The magnitude of this influence is shown by the correlation coefficient of 0.633 and the path coefficient of 0.406 . This indicates that managerial skills can improve job satisfaction.

The results of this study are in line with the idea of Michael K. Badawy (1995: 75-76). He suggested that there is influence between managerial skills and job satisfaction. Profesional Managerial Skills and attitudes to keep up with development in his field: to work with his colleague-subordinates, who have diverse orientation and research interest: and to create a climate conductive to their creativity, imagination, and job satisfaction.

This is also explained by Robbins (2001:149), he stated that managerial leadership skills is the determinant of job satisfaction.

The other opinion is proposed by Alka Dwivedi (2010:14), he stated that managerial skills affect job satisfacition. The higher the managerial skills, the better the level of job satisfacition.

\section{The Influence of Commitment to Job Satisfaction:-}

The results of this study indicate that commitment gives a direct positive influence to job satisfaction. The magnitude of the effect is shown by the correlation coefficient of 0.655 and the path coefficient of 0.452 . This indicates that commitment can increase job satisfaction.

The results of this study are in line with the opinion of Bengt Furaker (2011: 51). He said that there is an influence between commitment and job satisfaction. It turns out that the majority, 57 percent, of agency workers are committed to at least one of the organziations, most often to the user firm. Moreover, they are commited to the two organizations for different reasons, although a few similarities appear. Job Satisfaction is undoubtedly important in explaining commitment, which has also been emphasized by often research, it is linked to the workplace and therefore influences commitment. 
Meanwhile, Poznanski and Bline (1997:12) suggested that organizational commitment and job satisfaction are two things that are often taken into consideration when assessing employees who work.

Then it also reinforced by Jason A. Colquitt (2015: 105), he said that job satisfaction is one several individual mechanisms that directly affect job performance and organizational commitment.

\section{The Influence of Managerial Skills to Commitment:-}

The results of this study indicate that managerial ability gives a direct positive influence to commitment. The magnitude of the effect is shown by the correlation coefficient 0.502 and the path coefficient 0.502 . This indicates that managerial skills can affect commitment.

The results of this study are in line with the opinion of Dragan Z. Milosevic (2003: 350). He said that there is an influence between managerial ability with commitment. Involve the proper understanding of the criteria and organizational dynamics that drive commitment, and the managerial skills of negotiating commitments that align project requirement with the professional and personal needs of the team members.

Then it is also clarified by Dragan Z. Milosevic (2003: 353), he said that tools and concept that support team planning is managerial skills, skill building, interface management and commitment.

Meanwhile, Batemen and Snell (2015:12) said that managerial skill is the proces of working with people to accomplish commitment to work.

\section{Conclusion:-}

1. Managerial ability has a direct positive influence to job satisfaction. That is, the increase in managerial ability resulted in increased job satisfaction of MTs Private school principals in South Tangerang City and Tangerang Regency.

2. Commitment has a direct positive influence to job satisfaction. That is, the increase of commitment leads to increase job satisfaction of MTs Private school principals in South Tangerang City and Tangerang Regency.

3. Managerial ability has a direct positive influence to commitment. This means that improving managerial ability affects the commitment of MTs private school principals in South Tangerang City and Tangerang Regency.

\section{Suggestion:-}

First, for the Department of Education Kemenag of South Tangerang City and Tangerang Regency as poliy makers need to pay attention to various variables related to job satisfaction of principals in Madrasah Tsanawiyah (MTs). Managerial and commitment skills are highly recommended variables to be considered and applied for teachers to have job satisfaction in line with expectations.

Second, for the principal, they need to; (1) Provide a positive reciprocal of each program and policy issued by the education office; (2) Establish a good relationship with the principal and must always be active from every program that is issued; (3) Provide opportunities for school members to participate in school construction.

Third, for other researchers, they need to follow up this research through similar studies by developing the independent variables and the scope of the study area. This is due to many factors that affect managerial ability, commitment and job satisfaction. 


\section{References:-}

1. Badawy, Michael K. Developing Managerial Skills in Enginers and Scientists. USA, John Wiley and Sons Press, 1995.

2. Bateman, Thomas S, Scott A. Snell, Management Leading and Collaborating in the competitive world 11 edition. New York, McGraw-Hill, 2015.

3. Bloom, Benjamin S, Texonomy of Educational Objectives; The Classification of Educational Goals. New York: Longman, 1984.

4. Cohen, Aron. Multiple Commitments in the Workplace, An integrative Approach. New Jersey: Lawrence Erlbaun Associates, 2003.

5. Colquitt, Jason A.Jeffery A. Lepine and Michael J. Wesson, Organizattional Behavior Improving perfomance and Commitmen in The Workplace, New York McGraw-Hil, 2015.

6. Furaker, Bengt, Kristina Hakansson and Jan Ch. Karlssoon, Commitment to Work and Job Satisfaction. Swedia, Routledge,2011.

7. George, Jennifer M. and Garent R. Jones, Understanding and Managing Organizational Behavior. New Jersey: Pearson Prentice Hall, 2005.

8. Gibso James L. James H. Donnelly, JT, Jhon M. Ivamceicvh, Robert Konopakse, Organizational Behavior, Strukture, processes Fouteenth Editions. New York: McGraw-Hill, 2012.

9. Hellriegel, Don, Jhon W. Slocum, JR. Organizational Behavior 13 Edition. South Western: Cengage Learning, 2011.

10. Ikbal, Barlian. Manajemen berbasis Sekolah Menuju Sekolah berprestasi. Jakarta Erlangga, 2013.

11. Kinicki, Angelo, Brian K. Wiliams, Management a Practical Introduction. New York:McGraw-Hill, 2011.

12. Luthans, Fred. Organization Behavior An Evdence Based Approach. New York: Mc Graw-Hill, 2011.

13. Mc Shane, Steven L., Mary Ann Von Glinow, Organization Behavior Emerging Knowledge an Practice for the real world. New York:McGraw Hill, 2010.

14. Meyer, John H. dan Natalie J. Allien, A Three-Component Conceptualization of Organizational Comitment, Human Resource Management Review, Volume 1, Number 1, 1991.

15. Millmore, Mike, Lewis Philip, Saunders Mark, Adrian Thomhill and Trevor Morrow, Strategy Humen Resource Management. Harlow: Prentice Hall, 2007.

16. Milosevic, Dragan Z. Project Management ToolBox. USA, John Wiley and Sons Press, 2003.

17. Mullins, Laure J.Management \& Ogranizational Behavior 9 Edition. England:Prentice Hall, 2010.

18. Mulyasa. Menjadi Kepala Sekolah Profesional dalam kontes MBS dan KBK. Bandung : PT. Remaja Rosdakarya, 2005.

19. Oxford Dictionaries, The World's Most Stuted Dictionaries, (http://oxforddictionaries.com/view/entry/m en us 1261368\#m en us 1261368).

20. Permendiknas nomor 13 tahun 2007 tentaang standar kepala sekolah.

21. Richard L. Daft, Management 8 edition. South-Westren: Thomson, 2008.

22. Richard Mc Dermott, "Why Information Tecnology Inspired but Cannot Deliver Knowlwgde Management". California Management Review, 41, no. 4 Summer 1999, pp. 103-107, dalam Richard L. Daft, New Era of Management. Canada: South Western, 2010.

23. Robbins, Stephen P and Mary Coulter, Management eleventh edition. New Jersey: Prentice, hall 2012.

24. Robbins, Stephen P. Timothy A. Judge, Organization Behavior Fifteenth Edition. New Jersey: Prenticehall, 2003.

25. Robert Kreitner and Angelo Kinicki, Organization Behavior 9 edition. New York: McGraw-Hill, 2010.

26. Robert, Lussier N, Humen Relations in Organizationals Aplications and skillBuilding, Ninth Edition. New York: McGraw-Hill, 2013.

27. Schermerhon, John R.Introduction to management Twelfth edition. Asia: Wiley, 2011.

28. Schermerhorn, John R., James G. Hunt and Richard N. Osborn, Organizational Behavior, Twelfth Edition. USA: John Wiley \& Sons, 2012.

29. Undang-undang No. 20 Tahun 2003, Tentang Sistem Pendidikan NasionalJakarta: Depdiknas, 2003.

30. Wagner, John A. dan John R. Hollenberg, Organization behavior, Securing Competitive Advantage. New York: Routledge, 2010. 